The 29th Lung Cancer Mass Screening Seminar

\title{
がん対策とがん検診
}

\author{
祖父江友孝1
}

\section{Cancer Control and Cancer Screening}

Tomotaka Sobue 1

${ }^{1}$ Division of Environmental Medicine and Population Sciences, Graduate School of Medicine Osaka University, Japan.

ABSTRACT - The Cancer Control Act was approved in 2006, and the Basic Plan to Promote Cancer Control Programs was established in 2007. Since then, it has been shown that cancer control should be implemented comprehensively, as indicated in the Basic Plan. The primary aim of cancer control is to reduce the cancer incidence and mortality rates, and cancer screening is one of the important tools that can be used to achieve this goal. Scientific evidence of the efficacy of cancer screening should be accumulated in terms of the reduction in mortality for the target site. In addition, it is necessary to show that the benefits of cancer screening, such as mortality reduction, exceed the harms, such as false positive findings and overdiagnosis. The magnitude of these benefits and harms differ by age. It is expected that the age group that will have the best benefit/harm balance is 50-69 years old in males, but no suitable system for providing cancer screening is available for this age group. Namely, strategy-oriented cancer screening programs are mainly provided by the local government based on the Health Promotion Act, but this system generally only covers the elderly population. For those aged 50-69, who are generally still working, cancer screening is provide as part of the social welfare program by the employee's company or health insurance system, with no legislative basis. It is therefore time to reconsider the system used to provide cancer screening.

KEY WORDS — Cancer control, Cancer screening, Benefit/harm balance

(JJLC. 2015;55:257-260)

要旨一 2006 年にがん対策基本法が成立し，2007 年に がん対策推進基本計画が策定されて,わが国においても, がん対策を総合的かつ計画的に推進する方向性が示され た．がん対策の目的は，第一に，がんの罹患と死亡を減 少させることであり，がん検診は，がん死亡を減少させ るための重要な対策の 1 つである．科学的根拠のあるが ん検診とは, 対象とするがんの死亡率減少効果について の研究成果がある検診のこととされてきたが，近年では 一歩進んで，がん死亡減少をはじめとする利益と，偽陽 性や過剩診断などの不利益とのバランスを考慮し，利益 が不利益を上回るとする証拠があることが要求される.
利益不利益の内容と大きさは, 年齢によって異なる. が ん検診の利益不利益バランスが最も良好となる年齢層 は, 男性の場合, 50〜69 歳の中年層と想定されるが, こ れらの年齢に対しての検診提供体制が系統的に整備され ていない. すなわち, 健康増進法に基づく市町村がん検 診が現状においては対策型検診の中心であるにもかかわ らず, 高齢層の受診が多く, 中年層を対象とする職域に おけるがん検診は，法律に基づかない事業者あるいは保 険者の福利厚生事業として実施されている. 検診提供体 制についての抜本的な検討が必要な時期に来ている.

索引用語——がん対策, がん検診, 利益不利益バランス

1 大阪大学大学院医学系研究科社会医学講座環境医学. 


\section{わが国のがん対策}

わが国では, 1981 年にがんが死因の第一位になって以 降，がん対策が害施されてきた，厚労省の示すがん対策 の歩みには，1984 年から始まる「対がん 10 か年総合戦 略」「がん克服新 10 か年戦略」第 3 次対がん 10 か年総合 戦略」ががん対策として紹介されることがあるが，これ はがん研究費配分の仕組みであって，がん対策そのもの ではない. 1982 年の老人保健法によりがん対策の一部と してのがん検診が国の事業として開始されたことの方 が，がん対策としての取り組みの始まりといえる，さら に，がん対策全般として国レベルの取り組みが始まった のは, 2006 年のがん対策基本法からといえる. がん対策 基本法では, 基本理念として, (1)研究の推進とその成果 の活用 (Evidence-based), (2)がん医療の均てん化 (Equal Accessibility)，(3)患者中心の医療 (Patient-centered) が 謳われている.

2002 年に WHO も国家的がん対策プログラム（National Cancer Control Program）の推進を提唱している (WHO, 2002). その目的とするところは, 第一に, がんの 罹患率と死亡率を減少させることであり，第二に，がん 患者とその家族の QOL (Quality of Life) を向上させるこ とである.この 2 つの目的を達成するため, 予防・早期 発見・診断・治療・終末期ケアからなる一連のがん対策 において，証拠に基づいた戦略を系統的にかつ公平に実 行し，限られた資源を効率よく最大限に活用することが 求められる。この背景には，がん対策を進めるにあたっ て, 新しい診断・治療法を開発することも重要だが, 既 存の知識技術だけでも, かなりの程度目的を達成するこ とは可能である，という認識がある。すなわち，現在の がんの $1 / 3$ は現在の知識で予防可能, $1 / 3$ は検診・治療 で救命可能, 残りは治療・緩和ケアで QOL 向上可能で あり，問題は，既存の知識・技術に基づいた対策を如何 に実行するかにかかっており，国レベルでの計画的な取 り組みが必要との認識である。これに伴い，新規技術の 開発のための研究だけでなく，既存の知識・技術の普及 実施のための研究（Dissemination and Implementation Research）の重要性が認識されつつある.

\section{わが国におけるがん検診の経緯}

わが国のがん検診は, 1960 年代に X 線による胃がん検 診, 細胞診による子宮澒がん検診が臨床家の篤志的な試 みとして開始されたことに端を発するが，国レベルの政 策として初めて導入されたのが, 1983 年の老人保健法に よる保健事業としての胃がん・子宮䅡がん検診である. これは，国・都道府県・市町村が一体となってがん検診 に取り組むという，当時としては国際的にみても画期的
な政策であった．ところが，5年ごとの見直しのたびに， 有効性（当該がんの死亡減少効果）についての科学的根 拠が明らかでないままに対象部位を拡大したため, 有効 性の有無に関しての論議が巻き起こった. そのため,ケー ス・コントロール研究を主体とする有効性評価研究が, 政策として導入された後に, 事後的に実施された. 幸い, 多くの部位においては有効性が確認される結果となり, 2001 年の久道班報告書によって一応の決着を得たが, 国 際的にみると, ケース・コントロール研究のみによる成 果では, 証拠のレベルが弱いといわざるを得ない. また, 当時がん検診以外のがん予防対策（例えば，喫煙対策な ど）がほとんど進められていなかったことを考えると， がん予防対策ががん検診に偏重していたことも事実であ る.

一方，ほほ同じ時期の 1998 年に, がん検診が老人保健 法による保健事業から一般財源化され, 法律に基づかな い市町村事業へと位置づけが変更された。これは，当時 の地方分権の流れで，用途の限られた補助金を，市町村 の裁量で用途を決定できる地方交付税に振り替えるとい う理由で行われたが，結果としては，国レベルの指針に よる標準化促進と逆行し, 市町村レベルの検診体制に大 きなばらつきをもたらす最悪の施策となった。ただし， 久道班報告書を引き継ぐ形で, 厚労省研究班がガイドラ インを作成し, 厚労省に設置された「がん検診に関する 検討会」で指針の内容を更新する枠組みが定着しつつ あった。 その後, 循環器健診が老人保健事業から特定健 診に移行する際に, 市町村が行うがん検診は, 健康増進 法に基づく事業と位置づけられた。

2006 年にがん対策基本法が成立し, 2007 年にがん対策 推進基本計画が策定された，がん検診は，がん対策の一 環として実施されるもの（対策型検診）とそうでないも の（任意型検診）に区別され, 対策型検診の受診率や精 度管理が議論されることになった．特に，OECD Health Data などで,わが国のがん検診受診率が欧米諸国に比べ て著しく低いことが指摘されたため，2009 年には「がん 検診 $50 \%$ 推進本部」が設置され，「女性特有のがん検診 推進事業」(いわゆる無料クーポンの配布) が開始された が, 中央から提案する施策と地方での害情が今一つ噛み 合わない印象が否めない。

\section{がん検診の利益と不利益}

近年，がん検診のもたらす不利益に関する関心が高 まっている. がん検診の最大の利益は，目的とするがん の死亡を減らすことにあるが，その他に，がん患者の QOL の向上, 医療費削減, 真陰性者 (がんでない人が検 診で陰性といわれる場合)への安心などがある. 一方で, がん検診がもたらす不利益として，偽陰性者（がんであ 
Table 1. Grade of Recommendation by the US Preventive Services Task Force

\begin{tabular}{|c|c|c|c|c|}
\hline \multirow{2}{*}{$\begin{array}{r}\text { Site } \\
\text { Breast }\end{array}$} & \multirow{2}{*}{$\begin{array}{c}\text { Year policy was updated } \\
2009\end{array}$} & \multicolumn{3}{|c|}{ Grade of recommendation } \\
\hline & & $\begin{array}{c}\text { Less than } 50 \text { years old } \\
\text { C }\end{array}$ & $\begin{array}{c}\text { 50-74 years old } \\
\text { B }\end{array}$ & $\begin{array}{c}\text { Over } 75 \text { years old } \\
\text { I }\end{array}$ \\
\hline Cervix & 2012 & $\begin{array}{c}\text { Less than } 21 \text { years old } \\
\text { D }\end{array}$ & $\begin{array}{c}21-65 \text { years old } \\
\text { A }\end{array}$ & $\begin{array}{c}\text { Over } 65 \text { years old } \\
\text { D }\end{array}$ \\
\hline Colorectum & 2008 & $\begin{array}{l}\text { 50-75 years old } \\
\text { A }\end{array}$ & $\begin{array}{l}\text { 76-85 years old } \\
\text { C }\end{array}$ & $\begin{array}{c}\text { Over } 85 \text { years old } \\
\text { D }\end{array}$ \\
\hline Prostate & 2012 & & $\mathrm{D}$ & \\
\hline
\end{tabular}

る人が検診で陰性といわれる場合）の治療遅延，偽陽性 者（がんでない人が検診で陽性といわれる場合）への不 必要な精密検査に加えて, 寿命を全うするまでに症状を 呈さない進行の遅いがんを検診でみつけて治療してしま う「過剩診断」がある。こうした検診のもたらす不利益 のうち, 問題として大きいのは偽陽性と過剩診断である が, これらは当事者（受診者，検診提供者）にとって， 不利益と認識されない場合が多い.

検診のもたらす利益のうち, 死亡率減少効果について は, 個人単位のランダム割り付けによる比較研究 $(\mathrm{RCT}$, Randomized Controlled Trial）による評価が国際標準で あり，諸外国を含めて実証的なデータの蓄積がある. し かし，1つの RCT で検証できるのは，検診間隔，検診開 始年歯令，中止年齢に関して 1 つのパターンの場合の死亡 減少効果だけであって, 他のパターンによる効果は, 厳 密な意味では RCT を繰り返し行わないと答えが出な い.しかし， RCT は莫大な費用と時間を要するため, こ れに代わる方法として, マイクロシミュレーションなど 数理モデルによるアプローチが使われるよjになってき ている，不利益に関しては，研究というよりも事業の中 での計測が可能な指標（偽陽性率など）もあるが, 利益 と同様, 数理モデルによるアプローチも使われ始めてい る. 1

がん検診は，利益が不利益を上回ると判断される場合 に実施されるべきであるが，対策型検診においては，こ の判断を集団レベルで行い, 任意型検診においては個人 レベルで行うことになる，厚労省研究班においては，対 策型検診と任意型検診とに分けて，各種がん検診の推奨 レベルを決定し, 検診ガイドラインとして公表してきた. 検診ガイドラインは, 複数の機関が同一の課題について 取り扱うことがありうるが，時として推奨の内容が食い 違う場合がある。このような場合に対応するために，ア メリカの IOM（Institute of Medicine）では,「信頼され る診療ガイドラインを作成するための基準」を公開して いる. 2

科学的根拠のあるがん検診とは, 対象とするがんの死 亡率を減少させる効果があることを示す研究成果がある
と判断される検診のことと解釈されてきたが，近年では 一歩進んで, がん死亡減少をはじめとする「利益」と, 偽陽性や過剰診断などの「不利益」とのバランスを考慮 し，「利益」が「不利益」を上回るとする証拠があること が要求される.

米国予防医学サービス特別委員会 (USPSTF, US Preventive Services Task Force)では, 推奨グレードの判断 基準を 2007 年に改訂し, 利益が不利益を上回るとする証 拠がある場合をグレード A または B(検診を推奨する)， 利益が不利益と近接している場合を C（個人レベルで判 断する), 不利益が利益を上回るとする証拠がある場合を $\mathrm{D}$ (推奨しない), 判断する証拠が不十分な場合を I (推奨 についての判断せず）とする基準を示した. ${ }^{3}$ すなわち, 利益とともに不利益についても科学的証拠を積み上げ て, 判断材料の重要な要素とすべきいう考えが強調され るようになってきている.

\section{年齢別にみた利益不利益バランス}

2012 年に USPSTF が推奨グレード D と判断して大き な問題提起となったのが, PSA を用いた前立腺がん検診 であるが, 他にも推奨グレード D とされているのが, 高 齢者における大腸がん検診, 子宮頝がん検診, および, 若年者における子宮䅡がん検診がある (Table 1). 利益不 利益の内容と大きさは，年齢によって異なる．利益の大 きさは, 死亡率が年歯とともに増加するため, 死亡減少 の大きさも年歯とともに増加するが, 余命との関係で, ある年歯令上では減少する。一方, 不利益は, 若年層で は偽陽性・放射線被ばく，高齢層では過剩診断・合併症 など, 複数の要素から構成され，一般的には，中年期に 低く, 若年・高齢で高いU 字型の傾向をとることが想定 される (Figure 1)。こうした点を考慮して，今後は，検 診ガイドラインにおいても年齢別に推奨グレードを設定 していく必要がある.さらに，高歯者においては，合併 症による余命の違いなどで, 利益不利益バランスが個人 によって大きく異なることが考えられるので, その点も 含めて検討することが望ましい.

高齢者に対するがん検診は，受診者本人が受ける不利 


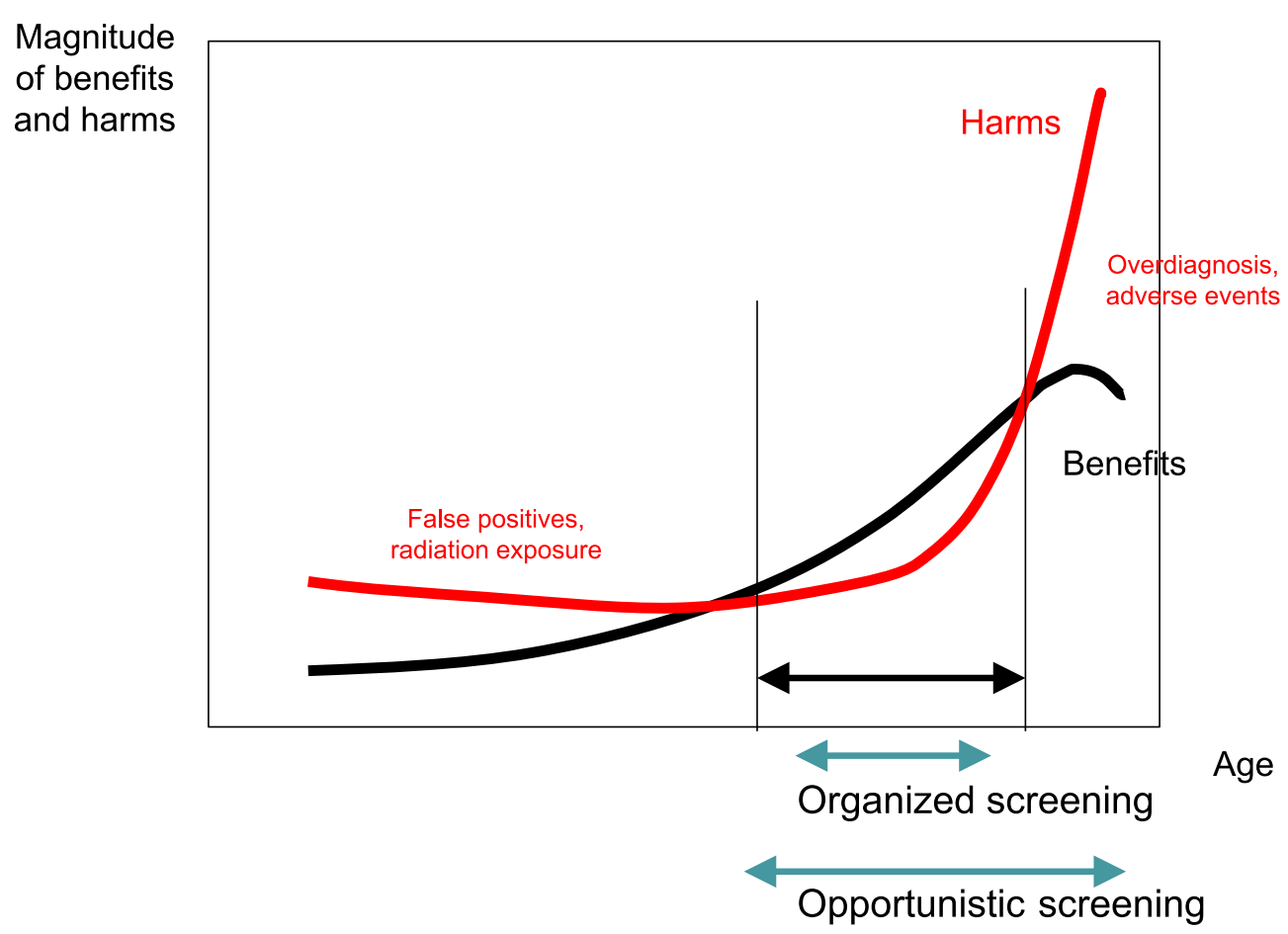

Figure 1. The magnitude of benefits and harms according to age (imaginary schematic illustration).

益が利益に比べて大きいことが多い.がん検診は，働き 盛りの年齢層こそ重点的に受診すべきであり，職域にお けるがん検診を体系化していくことも重要である. 現在, 特定健診とがん検診でずれを生じている実施主体につい ても，いずれかに統一することが強く望まれる.

一方, 受診率についても, 年齢別の対策を考慮する必 要がある. がん検診の利益不利益バランスが最も良好と なる年齢層は, 男性の場合, 50〜69歳の中年層と想定さ れるが，これらの年齢に対しての検診提供体制が系統的 に整備されていない.すなわち，健康増進法に基づく市 町村がん検診が現状においては対策型検診の中心である にもかかわらず, 高齢層の受診が多く, 中年層を対象と する職域におけるがん検診は，法律に基づかない事業者 あるいは保険者の福利厚生事業として実施されている. 検診提供体制についての抜本的な検討が必要な時期に来 ている.

\section{今後の方向性}

2012 年の新基本計画では,「5 年以内に, 全ての市町村 が，精度管理・事業評価を実施するとともに，科学的根 拠に基づくがん検診を実施することを目標とする」，「が ん検診の受診率については，5年以内に $50 \%$ （胃，肺， 大腸は当面 $40 \%$ ）を達成することを目標とする. 目標值 については，中間評価を踏まえ必要な見直しを行う。ま
た，健康増進法に基づくがん検診では，年齢制限の上限 を設けず， ある一定年齢以上の者を対象としているが, 受診率の算定に当たっては, 海外諸国との比較等も踏ま え, 40 歳から 69 歳 (子宮頸がんは 20 歳から 69 歳)まで を対象とする」,「がん検診の項目や方法については, 国 内外の知見を収集して検討し，科学的根拠のあるがん検 診の実施を目標とする」,の 3 点が個別目標として記述さ れた。今回のがん対策推進基本計画で，受診率の算定の 際に年齢上限を設けることが記述されたことは画期的な ことである. 今後は, 高齢者のがん検診, 職域のがん検 診の観点から, 検診提供体制についての抜本的な検討が 必要な時期に来ている.

本論文内容に関連する著者の利益相反：なし

\section{REFERENCES}

1. Lansdorp-Vogelaar I, Gulati R, Mariotto AB, Schechter $\mathrm{CB}$, de Carvalho TM, Knudsen AB, et al. Personalized age of cancer screening cessation based on comorbid conditions: model estimates of harms and benefits. Ann Intern Med. 2014;161:104-112.

2. IOM report. Clinical Practice Guidelines We Can Trust. 2011. (http://www.iom.edu)

3. USPSTF. Grade Definitions. 2007. (http://www.uspreven tiveservicestaskforce.org) 